\title{
Influence of race and gender on the presentation of eosinophilic esophagitis
}

\author{
Sarah L.W. Sperry, BA ${ }^{1,2}$, John T. Woosley, MD PhD ${ }^{3}$, Nicholas J. Shaheen, MD MPH ${ }^{1,2}$, \\ and Evan S. Dellon, MD MPH ${ }^{1,2}$ \\ ${ }^{1}$ Center for Esophageal Diseases and Swallowing, Division of Gastroenterology and Hepatology, \\ Department of Medicine, University of North Carolina School of Medicine, Chapel Hill, NC \\ ${ }^{2}$ Center for Gastrointestinal Biology and Disease, Division of Gastroenterology and Hepatology, \\ Department of Medicine, University of North Carolina School of Medicine, Chapel Hill, NC \\ ${ }^{3}$ Department of Pathology and Laboratory Medicine, University of North Carolina School of \\ Medicine, Chapel Hill, NC
}

\section{Abstract}

Objectives-Eosinophilic esophagitis (EoE) is thought to be more common among males and Caucasians, but little is known about disease presentation among patients with different genders or racial backgrounds. Our aim was to determine the clinical, endoscopic and histologic characteristics of patients with EoE of different genders or racial backgrounds.

Methods-We conducted a retrospective study of the University of North Carolina (UNC) EoE clinicopathologic database between January 2000 and December 2008. Cases of EoE were defined per 2007 consensus guidelines and stratified by race and gender for comparison.

Results-208 incident EoE cases were identified (76\% male, mean age 26 years, $82 \%$ Caucasian, 12\% African American). Caucasians were older at diagnosis than African Americans (27.1 yrs vs. $19.0 \mathrm{yrs}, \mathrm{p}=0.05$ ), less likely to present with failure-to-thrive ( $9 \%$ vs. $30 \%, \mathrm{p}=0.002$ ), and more likely to have esophageal rings $(41 \%$ vs. $12 \%, \mathrm{p}=0.005)$. These findings persisted after stratification by age. A higher proportion of males were diagnosed under the age of 18 as compared with females ( $48 \%$ vs $64 \%, \mathrm{p}=0.05$ ). Males were more likely to report dysphagia and food impaction as symptoms ( $71 \%$ vs. $53 \%, \mathrm{p}=0.02$ and $35 \%$ vs. $20 \%, \mathrm{p}=0.05$, respectively), and these findings also persisted after stratification by age. The remainder of clinical, endoscopic, and histologic features did not differ by either race or gender.

Corresponding Author: Evan S. Dellon MD, CB\#7080, Bioinformatics Building, 130 Mason Farm Rd., UNC-CH, Chapel Hill, NC 27599-7080, Phone: (919) 966-2513, Fax: (919) 843-2508, edellon@med.unc.edu.

Specific author contributions (all authors approved the final draft):

Sperry: Study concept; data acquisition; analysis; interpretation; manuscript drafting/revision

Woosley: data acquisition; pathology review; critical revision

Shaheen: study concept and design; supervision; interpretation; critical revision

Dellon: study concept and design; data acquisition; analysis; interpretation; manuscript drafting/revision

Potential competing interests:

None for any of the authors 
Conclusions-While age and dysphagia differed by gender and race among EoE patients, the majority of symptoms and findings were not different across groups, even after stratification by age. Clinicians should maintain a high index of suspicion for EoE, regardless of race or gender, and obtain esophageal biopsies to confirm the diagnosis.

\section{Introduction}

First described in the literature in 1978, eosinophilic esophagitis (EoE) has become increasingly prevalent over the past decade (1-4). EoE is characterized by symptoms of esophageal dysfunction accompanied by typical histologic findings. Presentations can differ in children and adults. Children often have symptoms of feeding intolerance, regurgitation or vomiting, or failure to thrive while adults usually have symptoms of dysphagia, food impaction, refractory heart burn, or chest pain (5-9). The diagnosis is confirmed by esophageal biopsy showing a prominent esophageal eosinophilic infiltrate in the absence of other clinical causes of eosinophilia $(6,7)$.

While the epidemiology of EoE is not fully understood, it appears that the incidence of EoE is increasing beyond what would be expected by increased recognition alone $(3,5,10)$. Multiple studies have found that EoE is three to four times more common in men than in women, and patients are more likely to be Caucasian than other racial or ethnic groups $(7,8$, 11-16). However, the reasons for this are unknown and there is little understanding of the differences in disease presentation among EoE patients of different genders or with different racial backgrounds.

The purpose of this study was to assess the clinical, endoscopic, and histological differences between EoE patients with different racial backgrounds, and between men and women. We hypothesized that a higher proportion of men and Caucasians experienced symptoms such as dysphagia or chest pain and were more likely to have abnormal endoscopic findings.

\section{Methods}

We conducted a retrospective study of the University of North Carolina (UNC) EoE clinicopathologic database between January 2000 and December 2008. Details of the development of this database have previously been reported (5). In brief, potential cases were identified by querying our pathology database for every biopsy that included the word "eosinophil" in the report. Charts were then reviewed to confirm the diagnosis of EoE. Cases of EoE were defined per 2007 consensus guidelines (6). Specifically, subjects were required to have clinical symptoms of esophageal dysfunction, $\geq 15$ eosinophils in at least one high-power field (eos/hpf), and had other causes of esophageal eosinophilia, including reflux disease, excluded. GERD was excluded in EoE cases by documenting persistent esophageal eosinophilia despite acid suppression at the time of biopsy, by documenting persistent esophageal eosinophilia despite prior symptoms refractory to high-dose acidsuppression, or with negative $\mathrm{pH}$ monitoring. Of note, these cases had previously been characterized with confirmation of the diagnosis of EoE (5).

Pertinent data extracted from the chart review included: age; gender; race (as reported either in the general demographic page of the medical record or as recorded in the medical 
history); history of atopic disease including allergic rhinitis/sinusitis, asthma, or documented food allergy (demonstrated by either symptomatic evidence of allergy with reintroduction of a food or by testing directed by an Allergist); esophageal symptoms (ie. dysphagia, chest pain, regurgitation/vomiting); clinical indication for esophagogastroduodenoscopy (EGD); endoscopic findings as documented in the previously written procedure note; and dilation during EGD.

Histologic findings were extracted from pathology reports, and then archived pathology slides were re-reviewed by the study pathologist to determine eosinophil counts according to our validated protocol (17). In brief, the maximum eosinophil density (eosinophils $/ \mathrm{mm}^{2}$ ) was determined after examination of five microscopy fields. For purposes of comparison to previous studies, eosinophil density was then converted to eos/hpf for an assumed hpf size of $0.24 \mathrm{~mm}^{2}$, the size of an average field as reported in the literature $(18,19)$.

Descriptive statistics were used to summarize the findings. Because there were so few nonAfrican American EoE patients in other racial groups, we limited our main analysis of race to Caucasians vs African Americans. For bivariate analysis comparing Caucasians to African Americans, and males to females, means were compared using Student's t-test and proportions were compared with chi-square. For variables where data were not normally distributed, medians were compared using the Wilcoxon Rank-sum test. Because the clinical presentation of EoE can vary between adults and children, we also performed a stratified analysis with respect to both race and gender based on patient age at diagnosis (adults $\geq 18$ years vs children $<18$ years). Multivariate analysis to assess predictors of race and gender was performed with logistic regression, and to further take age of presentation into account. This study was approved by the UNC Institutional Review Board.

\section{Results}

Overall, 208 patients with a confirmed diagnosis of EoE were identified. The mean age was 25.7 years, with a range from 6 months to 78 years, and with $50 \%$ under the age of 18 . Subjects were $76 \%$ male. The racial breakdown was as follows: $82 \%$ of subjects were Caucasian, $12 \%$ were African American, $1 \%$ Asian, $1 \%$ Native American, $1 \%$ Hispanic, and $2 \%$ other/unknown.

\section{EoE and race}

Table 1 shows the comparison between Caucasian and African American subjects with EoE. Caucasians were significantly older at diagnosis than African American subjects $(27 \pm 19$ yrs vs. $19 \pm 19$ yrs, $\mathrm{p}=0.05)$, and more likely to report dysphagia as symptom ( $71 \%$ vs. $48 \%, \mathrm{p}=0.02$ ). African Americans were more likely to present with failure-to-thrive than Caucasians ( $30 \%$ vs. 9\%, $\mathrm{p}=0.002$ ). There was no significant association between race and atopic disease, gender, or any other clinical symptoms.

On endoscopic evaluation (Table 2), Caucasians were significantly more likely to have esophageal rings ( $41 \%$ vs. $12 \%, \mathrm{p}=0.005)$ and African Americans were more likely to have normal endoscopic findings ( $32 \%$ vs. $17 \%$ ) though this relationship was not significant ( $\mathrm{p}=$ 
0.07). There were no other significant associations between race and endoscopic findings, indication, or likelihood of undergoing dilation during the procedure.

The maximum esophageal epithelial eosinophil count in Caucasians and African-Americans was similar (105 \pm 100 vs $131 \pm 114$ eos/hpf, p = 0.24; Table 3). Other histologic findings, including the presence of eosinophil degranulation, eosinophilic microabscesses, or lamina propria fibrosis also did not differ between the groups.

\section{EoE and gender}

Male patients with EoE were diagnosed at an younger age than females, but this was not statistically significant ( $25 \pm 19$ vs $29 \pm 20 \mathrm{yrs} ; \mathrm{p}=0.19$; Table 1$)$. However, a higher proportion of males were diagnosed under the age of 18 in childhood as compared with females ( $48 \%$ vs $36 \%, p=0.05)$. Males were also more likely than females to report dysphagia or food impaction ( $71 \%$ vs. $53 \%, p=0.02$, and $35 \%$ vs. $20 \%, p=0.05$, respectively), but less likely to report abdominal pain or nausea ( $17 \%$ vs $40 \%, p=0.001$, and $9 \%$ vs $28 \%, p=0.002$, respectively). There was no significant association between gender and atopic disease, race, or other reported symptoms.

On endoscopic evaluation, there were no significant difference between male and females with EoE; indication for endoscopy, endoscopic findings including rings, linear furrows, white plaques/exudates, or esophageal strictures were similar between the two groups (Table 2).

The maximum esophageal epithelial eosinophil count in males and females was similar (105 \pm 96 vs $109 \pm 111$ eos/hpf, $\mathrm{p}=0.80$; Table 3 ). Other histologic findings, including the presence of eosinophil degranulation, eosinophilic microabscesses, or lamina propria fibrosis also did not differ between the groups.

\section{Stratification by age and multivariate analyses}

After stratification by age (supplemental Table), the proportion of patients with dysphagia was similar for adult Caucasians and adult African Americans, but in children there was a trend towards more dysphagia in Caucasians $(52 \%$ vs $27 \%, \mathrm{p}=0.07)$. Failure to thrive remained more common in African American children ( $40 \%$ vs $15 \%, \mathrm{p}=0.03$ ). The proportion of patients with esophageal rings was greater in Caucasian adults than African American adults (66\% vs 30\%, p = 0.02), and was also more common in Caucasian children, though this was not significant ( $11 \%$ vs $0 \%, \mathrm{p}=0.19)$. On multivariate analysis, odds of failure to thrive were increased for African-Americans (OR 3.48, 95\% CI 1.08-11.3), but dysphagia and esophageal rings were not independently associated with race.

For gender (supplemental Table), dysphagia and food impaction were more common in males regardless of age, but this was only statistically significant for adult males with dysphagia (93\% vs $68 \%, \mathrm{p}=0.001)$. Abdominal pain and nausea were less common in adults males compared with females ( $6 \%$ vs $38 \%$, p < 0.001 , and $5 \%$ vs $27 \%, \mathrm{p}=0.004$ ), but there were no differences in these symptoms for children. On multivariate analysis, odds of abdominal pain remained lower for males (OR 0.25, 95\% CI 0.09-0.72), and younger age was also independently associated with male gender (OR 1.03, 95\% CI 1.01-1.05). 


\section{Discussion}

Eosinophilic esophagitis (EoE) has become an increasingly prevalent esophageal disease contributing to substantial morbidity among both adults and children $(6,7)$. Many studies have consistently reported that EoE is far more common in males and Caucasians, but the reasons for this finding are unknown $(7,8,11-16,20,21)$. As there are few data examining differences in features of EoE by patient race and gender, our aim was to characterize clinical, endoscopic, and histologic findings associated with EoE among Caucasians and African-Americans, as well as among men and women.

Despite some suggestion in the literature of racial and gender differences in EoE, we observed remarkably few differences in features of EoE by either race or gender. With a few exceptions, the clinical presentations were similar, the endoscopic appearances were similar, and the histologic findings and eosinophil counts were similar. This observation would be consistent with preliminary data examining the EoE transcriptome where there did not appear to be differences in gene expression in male vs female EoE patients, though the transcriptome has yet to be analyzed by race (22). However, a younger age at diagnosis was seen both for African Americans and males. This may explain our findings that AfricanAmericans were more likely to present with failure-to-thrive, that Caucasians and males were more likely to report dysphagia and have esophageal rings, and the stratified analysis by age supports this. It is known that symptoms and endoscopic findings of EoE can vary by age $(2,5,7,8,11-16)$, with failure-to-thrive more common in young patients, and dysphagia and esophageal rings more common in older patients. It is not as clear, however, why age of diagnosis would vary by race. Recent data presented in abstract form corroborate some of our findings and suggest that there might be isolated differences in EoE presentation by race, including a younger age at diagnosis in African-Americans (23), more dysphagia in Caucasians (24-26), and more esophageal rings in Caucasians (26). If differential access to care was important in this disease, and the disease course was the same in African Americans and Caucasians, one might expect African Americans to present at an older age than Caucasians. This presents the interesting possibility that EoE may be a more aggressive disease in African Americans. Of note, in our cohort African Americans did present with a higher mean eosinophil count, and this difference, while not significant, deserves further attention in subsequent studies. Because we found no features apart from failure to thrive in African American children and abdominal and nausea in women that were independently able to predict EoE cases status either by race or by gender, clinicians should maintain a low threshold for taking biopsies in all patients undergoing upper endoscopy when EoE is on the differential.

One issue with these data is that because we do no know the "denominator", the number of people who are African American or Caucasian and receive their GI health care at our center, the present study design does not allow us to draw conclusions about whether EoE is more frequently seen among Caucasians than African Americans and other racial groups. However, we suggest that this common belief may be an artifact related to the composition of the underlying populations from which the study subjects were drawn. For example, at our center we report $12 \%$ of EoE cases are African American, and find that African Americans comprise $14 \%$ of the local county, $22 \%$ of the state, and $19 \%$ of the hospital 
population. If studies are compiled that report the racial composition of the EoE populations $(4,12-15,23-25,27-31)$, and this composition is compared to the racial breakdown of the geographic region of study, an interesting trend emerges (Table 4). While not universally true, in many cases (including for the present report) the proportion of African American EoE patients mirrors the proportion of African American residents in the surrounding region (Figure 1). While this comparison is not definitive (importantly, these academic medical centers have wide referral or cachement areas that do not necessarily represent the population of the region), it is provocative. Because no studies of the prevalence of EoE in a general population reflective of the racial make-up of the U.S. have been conducted, we do not know the true distribution by race. However, the fact that some centers report a large number of African-American EoE patients, a rate which approaches the proportion of African-Americans in the general population surrounding those centers $(23,28)$, calls into question the belief that EoE is a Caucasian-predominant disease. Perhaps the trends reported to date are due to detection, referral, and publication bias?

This study has several strengths and limitations to consider. We report on a large population of patients with a confirmed diagnosis of EoE, and are therefore able to stratify this population by race and by gender. Despite this large sample size, the vast majority of subjects were either Caucasian or African American, and our analysis was limited to these two racial groups. To date, there have been few published cases of EoE in the U.S. Hispanic or Asian-American populations $(23,32)$. We also fully characterized the patients from a clinical, endoscopic, and histologic standpoint to provide rich descriptive data. However, this was a retrospective, single-center study, so the results might not be generalizable and we were not able to confirm racial status beyond what was in the electronic medical and demographic records.

In summary, we found that while age and dysphagia differed by gender and race among EoE patients, the majority of symptoms, endoscopic findings and all histologic findings were not different across groups. Future studies could investigate whether the earlier presentation of African-American and male patients is due to the pathophysiology of EoE or is otherwise related to social or environmental factors. Clinicians should maintain a high index of suspicion for EoE in the context of appropriate clinical information, regardless of race or gender, and obtain esophageal biopsies to attempt to confirm the diagnosis of EoE.

\title{
Supplementary Material
}

Refer to Web version on PubMed Central for supplementary material.

\section{Acknowledgments}

\author{
Financial support: \\ This work was supported by a grant from the Doris Duke Charitable Foundation to the University of North \\ Carolina-Chapel Hill (SLWS), and NIH award number KL2RR025746 from the National Center for Research \\ Resources and a Junior Faculty Development Award from the American College of Gastroenterology (ESD). \\ The study sponsors had no role in the study design, collection, analysis, or interpretation of the data.
}




\section{Abbreviations}

$\begin{array}{ll}\text { EGD } & \text { esophagogastroduodenoscopy } \\ \text { EoE } & \text { eosinophilic esophagitis } \\ \text { eos/hpf } & \text { eosinophils per high-power field } \\ \text { GERD } & \text { gastroesophageal reflux disease } \\ \text { PPI } & \text { proton pump inhibitor } \\ \text { UNC } & \text { University of North Carolina }\end{array}$

\section{References}

1. Landres RT, Kuster GG, Strum WB. Eosinophilic esophagitis in a patient with vigorous achalasia. Gastroenterology. 1978; 74:1298-1301. [PubMed: 648822]

2. Noel RJ, Putnam PE, Rothenberg ME. Eosinophilic esophagitis. N Engl J Med. 2004; 351:940-1. [PubMed: 15329438]

3. Straumann A, Simon HU. Eosinophilic esophagitis: escalating epidemiology? J Allergy Clin Immunol. 2005; 115:418-9. [PubMed: 15696105]

4. Prasad GA, Alexander JA, Schleck CD, et al. Epidemiology of eosinophilic esophagitis over three decades in Olmsted County, Minnesota. Clin Gastroenterol Hepatol. 2009; 7:1055-61. [PubMed: 19577011]

5. Dellon ES, Gibbs WB, Fritchie KJ, et al. Clinical, endoscopic, and histologic findings distinguish eosinophilic esophagitis from gastroesophageal reflux disease. Clin Gastroenterol Hepatol. 2009; 104:2695-2703.

6. Furuta GT, Liacouras CA, Collins MH, et al. Eosinophilic esophagitis in children and adults: a systematic review and consensus recommendations for diagnosis and treatment. Gastroenterology. 2007; 133:1342-63. [PubMed: 17919504]

7. Liacouras CA, Furuta GT, Hirano I, et al. Eosinophilic esophagitis: Updated consensus recommendations for children and adults. J Allergy Clin Immunol. 2011

8. Katzka DA. Demographic data and symptoms of eosinophilic esophagitis in adults. Gastrointest Endosc Clin N Am. 2008; 18:25-32. viii. [PubMed: 18061099]

9. Putnam PE. Eosinophilic esophagitis in children: clinical manifestations. Gastrointest Endosc Clin N Am. 2008; 18:11-23. vii. [PubMed: 18061098]

10. Hruz P, Bussmann C, Heer P, et al. Escalating Epidemiology of Eosinophilic Esophagitis: 21 Years of Prospective Population-Based Documentation in Olten County. Gastroenterology. 2011; 140(Suppl 1):S238-9.

11. Straumann A, Spichtin HP, Grize L, et al. Natural history of primary eosinophilic esophagitis: a follow-up of 30 adult patients for up to 11.5 years. Gastroenterology. 2003; 125:1660-9. [PubMed: 14724818]

12. Franciosi JP, Tam V, Liacouras CA, et al. A case-control study of sociodemographic and geographic characteristics of 335 children with eosinophilic esophagitis. Clin Gastroenterol Hepatol. 2009; 7:415-9. [PubMed: 19118642]

13. Spergel JM, Brown-Whitehorn TF, Beausoleil JL, et al. 14 years of eosinophilic esophagitis: clinical features and prognosis. J Pediatr Gastroenterol Nutr. 2009; 48:30-6. [PubMed: 19172120]

14. Dohil R, Newbury R, Fox L, et al. Oral Viscous Budesonide Is Effective in Children With Eosinophilic Esophagitis in a Randomized, Placebo-controlled Trial. Gastroenterology. 2010

15. Mackenzie SH, Go M, Chadwick B, et al. Clinical trial: eosinophilic esophagitis in patients presenting with dysphagia: a prospective analysis. Aliment Pharmacol Ther. 2008; 28:1140-6. [PubMed: 18624788]

16. Chehade M, Sampson HA. Epidemiology and etiology of eosinophilic esophagitis. Gastrointest Endosc Clin N Am. 2008; 18:33-44. viii. [PubMed: 18061100] 
17. Dellon ES, Fritchie KJ, Rubinas TC, et al. Inter- and intraobserver reliability and validation of a new method for determination of eosinophil counts in patients with esophageal eosinophilia. Dig Dis Sci. 2010; 55:1940-9. [PubMed: 19830560]

18. Dellon ES, Aderoju A, Woosley JT, et al. Variability in diagnostic criteria for eosinophilic esophagitis: A systematic review. Am J Gastroenterol. 2007; 102:2300-13. [PubMed: 17617209]

19. Sperry SLW, Shaheen NJ, Dellon ES. Toward Uniformity in the Diagnosis of Eosinophilic Esophagitis (EoE): The Effect of Guidelines on Variability of Diagnostic Criteria for EoE. Am J Gastroenterol. 2011; 106:824-32. [PubMed: 21304500]

20. Assa'ad AH, Putnam PE, Collins MH, et al. Pediatric patients with eosinophilic esophagitis: an 8year follow-up. J Allergy Clin Immunol. 2007; 119:731-8. [PubMed: 17258309]

21. Collins MH, Blanchard C, Abonia JP, et al. Clinical, pathologic, and molecular characterization of familial eosinophilic esophagitis compared with sporadic cases. Clin Gastroenterol Hepatol. 2008; 6:621-9. [PubMed: 18434257]

22. Blanchard C, Mingler MK, Vicario M, et al. IL-13 involvement in eosinophilic esophagitis: transcriptome analysis and reversibility with glucocorticoids. J Allergy Clin Immunol. 2007; 120:1292-300. [PubMed: 18073124]

23. Sharma HP, Mansoor DK, Sprunger AC, et al. Racial disparities in the presentation of pediatric eosinophilic esophagitis. J Allergy Clin Immunol. 2011; 127:AB110.

24. Bohm M, Sebastiano C, Malik ZA, et al. Racial Differences in Symptoms and Endoscopic Findings in Adults With Eosinophilic Esophagitis: A 10 Year Experience in an Urban Hospital. Gastroenterology. 2011; 140(Suppl 1):S244.

25. Malik ZA, Bohm M, Sebastiano C, et al. Symptoms and Endoscopic Findings in Children With Eosinophilic Esophagitis Differ by Race: A 7 Year Experience in an Urban Hospital. Gastroenterology. 2011; 140(Suppl 1):S244-5.

26. Dias JA, Moawad FJ, Veerappan GR, et al. Differences between blacks and whites with eosinophilic esophagitis. Gastroenterology. 2010; 138(Suppl 1):S1074.

27. Prasad GA, Talley NJ, Romero Y, et al. Prevalence and Predictive Factors of Eosinophilic Esophagitis in Patients Presenting With Dysphagia: A Prospective Study. Am J Gastroenterol. 2007; 102:2627-32. [PubMed: 17764492]

28. Veerappan GR, Perry JL, Duncan TJ, et al. Prevalence of Eosinophilic Esophagitis in an Adult Population Undergoing Upper Endoscopy: A Prospective Study. Clin Gastroenterol Hepatol. 2009; 7:420-426. [PubMed: 19162236]

29. Shah A, Kagalwalla AF, Gonsalves N, et al. Histopathologic variability in children with eosinophilic esophagitis. Am J Gastroenterol. 2009; 104:716-21. [PubMed: 19209168]

30. Moawad FJ, Veerappan GR, Lake JM, et al. Correlation between eosinophilic oesophagitis and aeroallergens. Aliment Pharmacol Ther. 2010; 31:509-15. [PubMed: 19925501]

31. Gupta SK, Collins MH, Lewis JD, et al. Efficacy and Safety of Oral Budesonide Suspension (OBS) in Pediatric Subjects With Eosinophilic Esophagitis (EoE): Results From the Double-Blind, Placebo-Controlled PEER Study. Gastroenterology. 2011; 140(Suppl 1):S179.

32. Lopez KT, Kuwada SK, Thompson KS. Sociodemographic Characteristics and Clinical Associations Among Children Diagnosed With Eosinophilic Esophagitis in Hawaii. Gastroenterology. 2011; 140(Suppl 1):S245. 


\section{Study highlights}

\section{What is current knowledge?}

- Eosinophilic esophagitis (EoE) has been reported to be more common among males and Caucasians.

- Little is known about differences in disease presentation among patients with EoE and different genders or racial backgrounds.

What is new here?

- Caucasians were older at diagnosis with EoE than African Americans, less likely to present with failure-to-thrive, and more likely to have esophageal rings.

- Males were more likely to be diagnosed as children and report dysphagia or food impaction.

- However, the majority of symptoms, endoscopic, and histologic findings were not different across groups. 


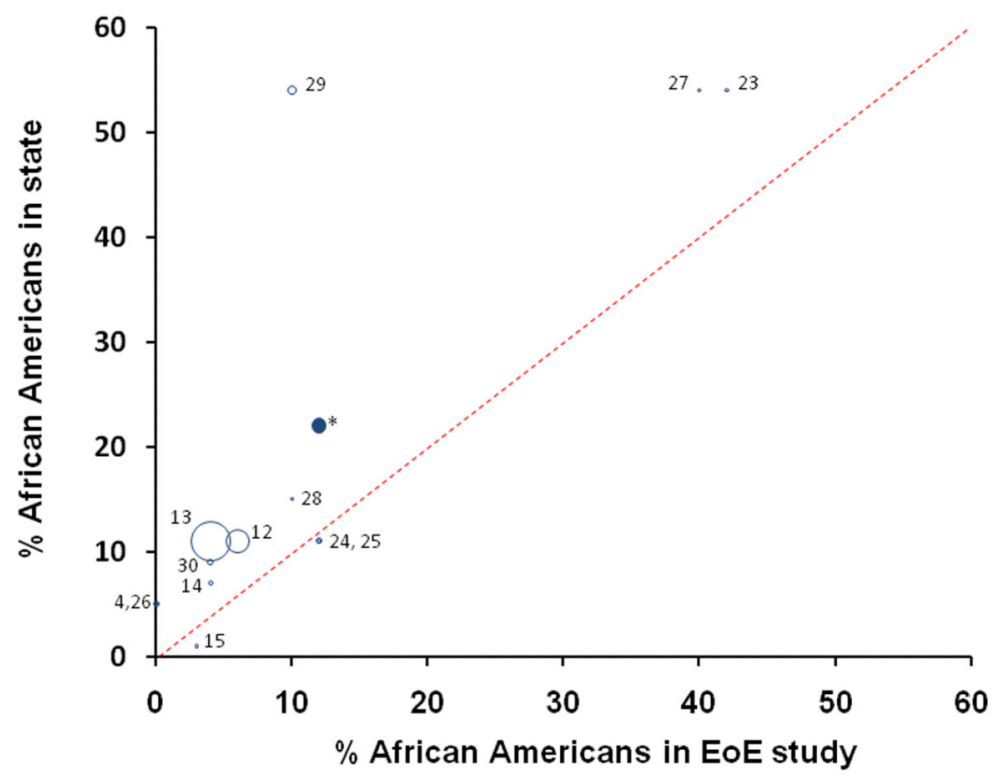

Figure 1.

The proportion of African American patients with EoE in selected studies related to the population proportion of African Americans in the state in which the health care center conducting the study is located. The size of each circle is proportional to the size of the study. The numbers next to the circles represent the reference number of the study. The solid blue circle with the asterisk is the present study. For the correlation between the proportion of African American patients in the studies and in the state, $r=0.82(p<0.001)$. 
Table 1

Patient characteristics

\begin{tabular}{|c|c|c|c|c|c|c|}
\hline & $\underset{(\mathrm{n}=170)}{\text { Caucasian }}$ & $\begin{array}{c}\text { African } \\
\text { American } \\
(\mathbf{n}=25)\end{array}$ & p-value ${ }^{\dagger}$ & $\begin{array}{c}\text { Male } \\
(n=158)\end{array}$ & $\begin{array}{c}\text { Female } \\
(\mathbf{n}=50)\end{array}$ & p-value ${ }^{\dagger}$ \\
\hline $\begin{array}{l}\text { Mean age at } \\
\quad \text { diagnosis/biopsy } \\
\text { (years } \pm \text { SD) }\end{array}$ & $27.1 \pm 19.0$ & $19.0 \pm 19.4$ & 0.05 & $24.7 \pm 18.9$ & $28.8 \pm 20.4$ & 0.19 \\
\hline \multicolumn{7}{|l|}{ Age $(\mathrm{n}, \%)$} \\
\hline Child ( $<18$ years) & $78(46)$ & $15(60)$ & 0.19 & $82(52)$ & $18(36)$ & 0.05 \\
\hline Adult ( $\geq 18$ years) & $92(54)$ & $10(40)$ & & $76(48)$ & $32(64)$ & \\
\hline \multicolumn{7}{|l|}{ Gender (n, \%) } \\
\hline Male & $133(78)$ & $18(72)$ & 0.5 & -- & -- & -- \\
\hline Female & $37(22)$ & $7(28)$ & & & & \\
\hline \multicolumn{7}{|l|}{ Race (n, \%) } \\
\hline Caucasian & -- & -- & -- & $133(84)$ & 37 (74) & 0.5 \\
\hline African American & & & & $18(11)$ & $7(14)$ & \\
\hline \multicolumn{7}{|l|}{ Symptoms (n, \%) } \\
\hline Dysphagia & $118(71)$ & $12(48)$ & 0.02 & $110(71)$ & $26(53)$ & 0.02 \\
\hline Food impaction & $53(34)$ & $4(17)$ & 0.1 & $49(35)$ & $9(20)$ & 0.05 \\
\hline Heartburn & $62(41)$ & $7(29)$ & 0.27 & $56(40)$ & $19(41)$ & 0.85 \\
\hline Chest pain & $12(8)$ & 0 & 0.16 & $9(7)$ & $4(9)$ & 0.65 \\
\hline Abdominal pain & $37(24)$ & $3(13)$ & 0.24 & $24(17)$ & $19(40)$ & 0.001 \\
\hline Nausea & $21(14)$ & $3(13)$ & 0.9 & $13(9)$ & $13(28)$ & 0.002 \\
\hline Vomiting & $36(24)$ & $8(35)$ & 0.26 & $33(24)$ & $13(28)$ & 0.61 \\
\hline Failure to thrive & $13(9)$ & $7(30)$ & 0.002 & $17(12)$ & $5(11)$ & 0.83 \\
\hline Any atopic disease (n, \%) & $78(58)$ & $10(53)$ & 0.65 & $70(56)$ & $22(58)$ & 0.84 \\
\hline \multicolumn{7}{|c|}{ Specified atopic diseases (n, \%) } \\
\hline Allergic rhinitis/sinusitis & $49(32)$ & $9(43)$ & 0.35 & $46(33)$ & $12(35)$ & 0.83 \\
\hline Food allergy & $25(23)$ & $3(19)$ & 0.73 & $22(21)$ & $7(21)$ & 0.99 \\
\hline Asthma & $41(27)$ & $3(15)$ & 0.25 & $34(25)$ & $12(27)$ & 0.71 \\
\hline
\end{tabular}

Am J Gastroenterol. Author manuscript; available in PMC 2015 September 27. 
Table 2

Endoscopy characteristics

\begin{tabular}{|c|c|c|c|c|c|c|}
\hline & Caucasian & $\begin{array}{l}\text { African } \\
\text { American }\end{array}$ & p-value ${ }^{\dagger}$ & Male & Female & p-value ${ }^{\dagger}$ \\
\hline $\begin{array}{l}\text { Primary EGD indication of dysphagia } \\
\quad(\mathrm{n}, \%)\end{array}$ & $90(54)$ & $9(38)$ & 0.13 & $83(54)$ & $21(43)$ & 0.17 \\
\hline $\begin{array}{l}\text { Primary EGD indication of heartburn } \\
\quad(\mathrm{n}, \%)\end{array}$ & $39(23)$ & $7(29)$ & 0.54 & $38(25)$ & $11(22)$ & 0.73 \\
\hline Other EGD indications ( $\mathrm{n}, \%)$ & & & 0.33 & & & 0.55 \\
\hline Food impaction alone & $7(4)$ & $2(8)$ & & $7(5)$ & $2(4)$ & \\
\hline Abdominal pain (any) & $20(12)$ & $2(8)$ & & $13(11)$ & $11(23)$ & \\
\hline Weight loss/failure to thrive & $5(3)$ & $3(13)$ & & $8(5)$ & $2(4)$ & \\
\hline Nausea and/or vomiting & $7(4)$ & $1(4)$ & & $6(4)$ & $2(4)$ & \\
\hline Chest pain & $3(2)$ & 0 & & $2(1)$ & $1(2)$ & \\
\hline Odynophagia & $2(1)$ & 0 & & $2(1)$ & 0 & \\
\hline Feeding intolerance & $2(1)$ & 0 & & $2(1)$ & 0 & \\
\hline \multicolumn{7}{|l|}{ EGD findings $(\mathrm{n}, \%)^{*}$} \\
\hline Normal & $28(17)$ & $8(32)$ & 0.07 & $29(19)$ & $12(24)$ & 0.42 \\
\hline Rings & $69(41)$ & $3(12)$ & 0.005 & $57(37)$ & $19(38)$ & 0.88 \\
\hline Stricture & $32(19)$ & $4(16)$ & 0.71 & $32(21)$ & $7(14)$ & 0.30 \\
\hline Narrowed esophagus & $16(10)$ & $1(4)$ & 0.36 & $12(8)$ & $6(12)$ & 0.36 \\
\hline Linear furrows & $49(29)$ & $4(16)$ & 0.16 & $43(28)$ & $13(26)$ & 0.81 \\
\hline "Crepe-paper" mucosa & $8(5)$ & $1(4)$ & 0.86 & $7(5)$ & $3(6)$ & 0.67 \\
\hline White plaques & $20(12)$ & $5(20)$ & 0.27 & $21(14)$ & $5(10)$ & 0.51 \\
\hline Erythema & $24(14)$ & $4(16)$ & 0.83 & $28(18)$ & $3(6)$ & 0.04 \\
\hline Decreased vascularity & $12(7)$ & $3(12)$ & 0.40 & $14(9)$ & $3(6)$ & 0.50 \\
\hline Erosive esophagitis & $53(32)$ & $6(24)$ & 0.43 & $50(32)$ & $12(24)$ & 0.27 \\
\hline Hiatal hernia & $12(7)$ & $1(4)$ & 0.56 & $7(4)$ & $7(14)$ & 0.02 \\
\hline Other findings $(\mathrm{n}, \%)^{*}$ & $44(26)$ & $5(20)$ & 0.53 & $41(26)$ & $11(22)$ & 0.57 \\
\hline Dilation performed (n, \%) & $34(20)$ & $5(20)$ & 0.96 & $35(23)$ & $8(16)$ & 0.35 \\
\hline \multicolumn{7}{|c|}{ p-values calculated with t-test for continuous variables and with chi-square for categorical variables } \\
\hline
\end{tabular}

Am J Gastroenterol. Author manuscript; available in PMC 2015 September 27. 


\section{Table 3}

Histology characteristics

\begin{tabular}{lcccccc}
\hline & White & Black & p-value $^{\dagger}$ & Male & Female & p-value $^{\ddagger}$ \\
\hline $\begin{array}{c}\text { Maximum eosinophil density } \\
\left(\text { mean eos } / \text { mm }^{2} \pm \text { SD) }\right.\end{array}$ & $438 \pm 415$ & $545 \pm 477$ & 0.24 & $437 \pm 399$ & $454 \pm 463$ & 0.80 \\
$\begin{array}{c}\text { Maximum eosinophil count } \\
(\text { mean eos/hpf } \pm \text { SD) }\end{array}$ & $105 \pm 100$ & $131 \pm 114$ & 0.24 & $105 \pm 96$ & $109 \pm 111$ & 0.80 \\
Eosinophil degranulation ${ }^{\dagger}$ & $84(92)$ & $15(94)$ & 0.84 & $84(95)$ & $22(85)$ & 0.06 \\
Eosinophil microabscesses ${ }^{\dagger}$ & $62(68)$ & $11(69)$ & 0.96 & $60(68)$ & $16(62)$ & 0.53 \\
Spongiosis present $_{\text {Subepithelial stroma present }}$ & $79(87)$ & $15(94)$ & 0.43 & $79(90)$ & $22(85)$ & 0.47 \\
Lamina propria fibrosis & $1(1)$ & $14(88)$ & 0.49 & $71(81)$ & $21(81)$ & 0.99 \\
\hline
\end{tabular}

The eosinophil count was calculated from the eosinophil density for an assumed hpf size of $0.24 \mathrm{~mm}^{2}$ with the following equation: eosinophil count $(\mathrm{eos} / \mathrm{hpf})=$ eosinophil density $\left(\mathrm{eos} / \mathrm{mm}^{2}\right) \times 0.24 \mathrm{~mm}^{2} / \mathrm{hpf}$.

$\dagger_{\text {any seen in biopsy specimen }}$

${ }_{\mathrm{p}}$ -

p-values calculated with t-test for continuous variables and with chi-square for categorical variables 
Table 4

Race and gender characteristics of EoE studies

\begin{tabular}{|c|c|c|c|c|c|c|}
\hline $\begin{array}{l}\text { Author and } \\
\text { publication }\end{array}$ & $\begin{array}{c}\text { Total n } \\
\text { in study } \\
\text { w/ EoE }\end{array}$ & Region & $\begin{array}{l}\text { African } \\
\text { Americans } \\
\text { in study } \\
(\%)\end{array}$ & $\begin{array}{l}\text { Caucasians in } \\
\text { study }(\%)\end{array}$ & $\begin{array}{c}\text { African } \\
\text { Americans in } \\
\text { county/state }{ }^{*}(\%)\end{array}$ & $\begin{array}{c}\text { Caucasians in } \\
\text { county/state } \\
(\%)\end{array}$ \\
\hline${ }^{*}$ present report & 208 & $\begin{array}{l}\text { UNC hospital- } \\
\text { Chapel Hill, NC } \\
\text { (Orange county) }\end{array}$ & 12 & 82 & $14 / 22$ & $78 / 74$ \\
\hline Prasad et al., AJG, 2007 & 33 & $\begin{array}{l}\text { Mayo Clinic- } \\
\text { Rochester, MN } \\
\text { (Olmsted county) }\end{array}$ & 0 & 100 & $4 / 5$ & $89 / 89$ \\
\hline $\begin{array}{l}\text { Mackenzie et al., Aliment Pharm } \\
\text { Ther, } 2008\end{array}$ & 31 & $\begin{array}{l}\text { University of } \\
\text { Utah and Salt } \\
\text { Lake Vet Affairs } \\
\text { Med Center- Salt } \\
\text { Lake City, UT } \\
\text { (Salt lake county) }\end{array}$ & 3 & 97 & $2 / 1$ & $90 / 93$ \\
\hline Franciosi et al., CGH, 2009 & 335 & $\begin{array}{c}\text { Children's } \\
\text { Hospital of } \\
\text { Philadelphia- } \\
\text { Philadelphia, PN } \\
\text { (Philadelphia } \\
\text { county) }\end{array}$ & 6 & 84 & $44 / 11$ & $49 / 85$ \\
\hline Prasad et al., CGH, 2009 & 78 & $\begin{array}{l}\text { Mayo Clinic- } \\
\text { Rochester, MN } \\
\text { (Olmsted county) }\end{array}$ & 0 & 100 & $4 / 5$ & $89 / 89$ \\
\hline Veerappan et al., CGH, 2009 & 25 & $\begin{array}{c}\text { Walter Reed } \\
\text { Army Medical } \\
\text { Center- } \\
\text { Washington, DC }\end{array}$ & 40 & 60 & 54 & 41 \\
\hline Shah et al., AJG, 2009 & 30 & $\begin{array}{l}\text { Children's } \\
\text { Memorial } \\
\text { Hospital, } \\
\text { Northwestern } \\
\text { University- } \\
\text { Chicago, IL } \\
\text { (Cook county) }\end{array}$ & 10 & 64 & $26 / 15$ & $67 / 79$ \\
\hline Spergel et al., J Ped Gastr Nutr, 2009 & 562 & $\begin{array}{c}\text { Children's } \\
\text { Hospital of } \\
\text { Philadelphia- } \\
\text { Philadelphia, PN } \\
\text { (Philadelphia } \\
\text { county) }\end{array}$ & 4 & 90 & $44 / 11$ & $49 / 85$ \\
\hline Dohil et al., Gastro, 2010 & 24 & $\begin{array}{c}\text { Rady Children's } \\
\text { Hospital, UCSD- } \\
\text { San Diego, CA } \\
\text { (San Diego } \\
\text { County) }\end{array}$ & 4 & 54 & $6 / 7$ & $79 / 76$ \\
\hline $\begin{array}{l}\text { Moawad et al., Alim Pharmaco Ther, } \\
\qquad 2010\end{array}$ & 127 & $\begin{array}{c}\text { Walter Reed } \\
\text { Army Medical } \\
\text { Center- } \\
\text { Washington, DC }\end{array}$ & 10 & 82 & 54 & 41 \\
\hline $\begin{array}{l}\text { Bohm et al., Gastro, } 2011 \\
\text { (abstract) }\end{array}$ & 71 & $\begin{array}{c}\text { Temple } \\
\text { University School } \\
\text { of Medicine- } \\
\text { Philadelphia, PN } \\
\text { (Philadelphia } \\
\text { county) }\end{array}$ & 12 & 82 & $44 / 11$ & $49 / 85$ \\
\hline $\begin{array}{l}\text { Gupta et al., Gastro, } 2011 \\
\text { (abstract) }\end{array}$ & 81 & $\begin{array}{c}\text { Indiana } \\
\text { University School } \\
\text { of Medicine- } \\
\text { Indianapolis, IN }\end{array}$ & 4 & 95 & $26 / 9$ & $70 / 88$ \\
\hline
\end{tabular}




\begin{tabular}{|c|c|c|c|c|c|c|}
\hline $\begin{array}{l}\text { Author and } \\
\text { publication }\end{array}$ & $\begin{array}{c}\text { Total n } \\
\text { in study } \\
\text { w/ EoE }\end{array}$ & Region & $\begin{array}{c}\text { African } \\
\text { Americans } \\
\text { in study } \\
(\%)\end{array}$ & $\begin{array}{l}\text { Caucasians in } \\
\text { study }(\%)\end{array}$ & $\begin{array}{c}\text { African } \\
\text { Americans in } \\
\text { county/state }{ }^{*}(\%)\end{array}$ & $\begin{array}{c}\text { Caucasians in } \\
\text { county/state } \\
(\%)\end{array}$ \\
\hline & & (Marion county) & & & & \\
\hline $\begin{array}{l}\text { Sharma et al., J AllerClinImmunol, } \\
2011 \text { (abstract) }\end{array}$ & 50 & $\begin{array}{c}\text { Children's } \\
\text { National Medical } \\
\text { Center- } \\
\text { Washington, } \\
\text { D.C. }\end{array}$ & 42 & 42 & 54 & 41 \\
\hline $\begin{array}{l}\text { Zubair Malik, et al., Gastro, } 2011 \\
\text { (abstract) }\end{array}$ & 34 & $\begin{array}{c}\text { Temple } \\
\text { University School } \\
\text { of Medicine- } \\
\text { Philadelphia, PN } \\
\text { (Philadelphia } \\
\text { county) }\end{array}$ & 12 & 63 & $44 / 11$ & $49 / 85$ \\
\hline
\end{tabular}

*US Census data (http://quickfacts.census.gov) 